\title{
Struktur Komunitas Plankton Perairan Payau di Kecamatan Wedung Kabupaten Demak
}

\author{
Isyarotuz Zakiyyah, Jafron Wasiq H dan Fuad Muhammad \\ Laboratorium Ekologi dan Biosistematik \\ Fakultas Sains dan Matematika, Universitas Diponegoro, Semarang \\ Jln Prof. Soedarto, SH,Semarang,50275, Telp: (024)7474754; Fax (024) 76480923 \\ Email isyarotuzzakiyyah@yahoo.co.id
}

\begin{abstract}
Aquaculture are highly prioritized by the government to support the economy. Products from the aquaculture sector is also targeted as a source of income to the Indonesian country. Aquaculture needs to improve to manage water quality, especially plankton to support natural food of the fish. This study aims to examines structure of plankton community in the brackish waters of the District Wedung and then examines the water quality with environmental quality standards of water the cultivation. Research was conducted in February-April 2015. The method used to analyze data that plankton with uses keanekargaman index $\left(\mathrm{H}^{\prime}\right)$ and the perataan index ( e ). The results showed that the number of species (genera) plankton obtained during research in the waters of the District Wedung was 45 species, these types consist of 37 species of phytoplankton and zooplankton 8 types. The most common plankton species found in all the stations were Fragillaria sp, Synedra ulna, Oscillatoria formosa and Copepod nauplius. Index of species diversity that existed at the District Wedung moderate to high waters with a range from 1.69 to 2.91 therefore a complex community and stability of the ecosystem were moderate to high. The evennes index ranged from 0.63 to 0.85 . Water quality based on the $\mathrm{pH}$, salinity, Turbidity, $\mathrm{N}, \mathrm{P}$ and organic materials are less good for the cultivation so that the necessary processing on the pond so that according to the criteria of the quality standards of water quality.
\end{abstract}

Keywords: structure of plankton communities, brackish waters, District Wedung

\begin{abstract}
Abstrak
Budidaya perairan sangat diprioritaskan oleh pemerintah untuk meningkatkan perekonomian. Produk dari sektor budidaya perairan juga ditargetkan sebagai sumber devisa pemasukan Negara Indonesia. Demikian halnya budidaya tambak yang perlu ditingkatkan dengan mengelola kualitas perairan, terutama plankton sehingga dapat mendukung pakan alaminya. Penelitian ini bertujuan untuk mengkaji struktur komunitas plankton di perairan payau Kecamatan Wedung, mengkaji kualitas air tambak dibandingkan dengan baku mutu lingkungan air budidaya. Penelitian dilaksanakan pada bulan Februari-April 2015. Metode yang digunakan dengan menganalisis data plankton menggunakan indeks keanekargaman $\left(\mathrm{H}^{\prime}\right)$ dan indeks perataan (e). Hasil penelitian menunjukkan bahwa jumlah jenis (genera) plankton yang diperoleh selama penelitian di perairan Kecamatan Wedung adalah 45 jenis, jenis tersebut terdiri atas fitoplankton 37 jenis dan zooplankton 8 jenis. Jenis plankton yang banyak ditemukan pada semua stasiun adalah Fragillaria sp, Synedra ulna, Oscillatoria formosa dan Copepod nauplius. Indeks keanekaragaman jenis yang ada pada perairan Kecamatan Wedung sedang sampai tinggi dengan kisaran 1,69-2,91, yang menggambarkan komunitas yang kompleks dan kestabilan ekosistemnya adalah sedang sampai tinggi. Adapun nilai indeks pemerataan berkisar antara 0,63-0,85 yang mennggambarkan bahwa tiap stasiun mempunyai pemerataan jenis sedang sampai tinggi. Kualitas air tambak berdasarkan $\mathrm{pH}$, salinitas, Turbiditas, N, P dan bahan organik kurang baik untuk budidaya sehingga perlu dilakukan pengolahan pada tambak agar sesuai dengan kriteria baku mutu kualitas air tambak..
\end{abstract}

Kata kunci: struktur komunitas plankton, perairan payau, Kecamatan Wedung

\section{PENDAHULUAN}

Struktur komunitas merupakan suatu kumpulan berbagai jenis organisme yang berinteraksi dalam suatu zonasi tertentu (Muharram, 2006). Struktur komunitas plankton merupakan kumpulan populasi plankton yang 
terdiri dari fitoplankton dan zooplankton pada suatu habitat tertentu yang saling berinteraksi di dalam suatu stratifikasi tertentu (Odum (1998). Dinamika kelimpahan dan struktur komunitas fitoplankton terutama dipengaruhi oleh faktor fisika dan kimia, khususnya ketersediaan unsur hara (nutrien) dan kualitas cahaya serta kemampuan fitoplankton untuk memanfaatkannya (Muharram, 2006). Termasuk komunitas plankton.

Sementara itu, permasalahan yang sering terjadi dalam budidaya tambak adalah teknik pembesaran untuk mencapai ukuran yang ditargetkan. Dua hal yang umum diupayakan yaitu menggunakan pakan tambahan dan meminimalkan tingkat kematian kultivan selama pemeliharaan. Kondisi demikian juga diterapkan di kawasan tambak di Kecamatan Wedung.

Plankton merupakan kornunitas mata rantai pertama dalam jejaring makanan, baik sebagai produsen primer maupun konsumen primer. Kelimpahan fitoplankton sangat ditentukan oleh tersedianya antara lain unsur hara, cahaya yang cukup, dan gerakan air. Fitoplankton mempunyai peran sebagai makanan zooplankton dan ikan (Champalbert dkk, 2007). Nilai kecerahan perairan ditentukan oleh banyak sedikitnya partikel yang melayang dalam air. Jika kecerahan diperairan rendah, maka jumlah partikel yang melayang dalam air tinggi. Partikel ini dapat berupa padatan atau plankton yang tersuspensi. Dengan banyaknya partikel ini maka cahaya matahari yang masuk ke perairan menjadi terhambat menembus sampai kedalaman yang lebih dalam.

Di kawasan pantura Demak, khususnya di Wedung saat ini banyak diperuntukkan sebagai tambak. Kawasan pantai ini mencapai luas 4.250,77 ha diperuntukkan sebagai bandeng/udang secara monokultur. Serta sebagian kecil diperuntukkan untuk tambak garam saat musim kemarau. Berdasarkan informasi petambak setempat, produktivitas tambak bandeng atau udang yang ada di Kecamatan Wedung mengalami penurunan dari tahun 2000-an yang dikaitkan dengan menurunnya berubahnya kualitas air. Diperlukan upaya untuk meningkatkan produktivitas tersebut. Kebanyakan tambak di Kecamatan Wedung diolah dengan cara tradisonal tanpa pakan. Untuk mengetahui kondisi tambak serta pakan alami yang ada di tambak perlu dilakukan penelitian terhadap kualitas air, salah satunya dengan mengetahui struktur plankton.

Oleh karena itu, perlu dilakukan pengkajian kualitas perairan, terutama planktonnya sehingga dapat diketahui kondisi tambak yang ada di Kecamatan Wedung. Hal ini selanjutnya untuk meningkatkan kualitas, produktivitas tambak dan perekonomian para nelayan. Diharapkan dengan dilakukannya hal tersebut ada peningkatan hasil dari tahun sebelumnya

\section{BAHAN DAN METODE Tempat dan Waktu Penelitian}

Penelitian dilaksanakan pada bulan FebruariApril 2015 dengan kondisi musim hujan. Sampling penelitian ini dilakukan di Kecamatan Wedung Kabupaten Demak. Sampel diambil dari perairan umum dan tambak.

\section{Cara Kerja \\ Penentuan Stasiun}

Stasiun penelitian ditentukan berdasarkan pemanfaatan area pertambakan dan perairan umum dari tambak yang jauh dari laut/pantai hingga mendekati area tambak yang dekat dengan laut. Penelitian ini dilakukan pada 5 stasiun yang masing-masing terdiri dari tambak dan perairan umum.

\section{Pengambilan Sampel Plankton}

Adapun cara pengambilan sampel dengan menggunakan plankton net dengan cara air disaring dengan volume 10 liter tiga kali ulangan. Selanjutnya, dilakukan pengawetan dengan formalin 4\% dan hasil diidentifikasi.

\section{Pengukuran Parameter Fisika dan Kimia}

Pengukuran parameter fisika dan kimia ini dilakukan secara in situ (dianalisis di lokasi penelitian) yang meliputi : $\mathrm{DO}$, suhu, salinitas, $\mathrm{pH}$, dan kekeruhan. Dan ex situ meliputi N, P dan bahan organik.

\section{Analisis Laboratorium \\ Analisis Plankton}

Analisis sampel plankton dilakukan di Laboratorium Ekologi dan Biosistematik Jurusan Biologi Fakultas Sains dan Matematika Universitas Diponegoro. 
Kelimpahan plankton dihitung berdasarkan rumus APHA (2005) :

$$
\mathrm{N}=\frac{T}{L} \times \frac{p 1}{P 2} \times \frac{V 1}{V 2} \times \frac{1}{W}
$$

Di mana :

$$
\begin{array}{lll}
\mathrm{N} & \text { : Kelimpahan plankton (ind/L) } \\
\mathrm{T} & \text { : Jumlah kotak dalam SRC (1000) } \\
\mathrm{L} & \text { : Jumlah kotak dalam satu lapang } \\
& \text { pandang } \\
\mathrm{P} 1 & \text { : Jumlah plankton yang teramati } \\
\mathrm{P} 2 & \text { : Jumlah kotak SRC yang diamati } \\
\mathrm{V} 1 & \text { : Volume air dalam botol sampel } \\
\mathrm{V} 2 & \text { : Volume air dalam kotak SRC } \\
\mathrm{W} & \text { : Volume air tambak/saluran } & \text { yang } \\
& \text { tersaring. }
\end{array}
$$

Analisis data dilakukan menggunakan indeks keanekaragaman (H') dan Indeks Perataan (e). Keanekaragaman plankton dihitung berdasarkan rumus Shannon Wiener (Magurran, 1988) :

$$
\begin{aligned}
& H^{\prime}=-\sum_{\mathrm{i}=1}^{\mathrm{n}} \mathrm{pi}^{\mathrm{ln}} \mathrm{pi}^{\mathrm{i}} \\
& \mathrm{pi}=\frac{n i}{N}
\end{aligned}
$$

Di mana :

$$
\begin{array}{ll}
\mathrm{H}^{\prime} & \text { : Indeks Keanekaragaman Shannon- } \\
& \text { Wiener. } \\
\mathrm{ni} & \text { : Jumlah genus ke-i. } \\
\mathrm{N} & \text { : Jumlah total genus. } \\
& \text { Perataan plankton dihitung dengan rumus : } \\
& \mathrm{E}=\frac{H^{\prime}}{\text { Hmaks }}
\end{array}
$$

Di mana :

$$
\begin{array}{ll}
\mathrm{E} & \text { :Indeks Perataan Genus } \\
\mathrm{H} & \text { :Indeks Keanekaragaman Genus } \\
\mathrm{H}_{\text {maks }} & \text { :Indeks Keanekaragaman Maksimum }
\end{array}
$$

\section{Analisis Parameter Fisika dan Kimia}

Analisis parameter fisika dan kimia dilakukan dengan analisis deskriptif. Dengan cara membandingkan parameter fisika kimia antar stasiun dengan standar baku mutu kualitas air.

\section{HASIL DAN PEMBAHASAN Struktur Komunitas Plankton}

Hasil pengamatan menunjukkan bahwa jumlah jenis (genera) plankton yang diperoleh selama penelitian di perairan Kecamatan Wedung adalah 45 jenis, jenis tersebut terdiri atas fitoplankton 37 jenis dan zooplankton 8 jenis. (Tabel 1). Jumlah jenis tersebut dinyatakan melimpah dibandingkan dengan penelitian yang dilakukan oleh Widowati (2004) yang melakukan kajian di tambak yang ada di Kabupaten Demak, yang hanya menemukan 26 jenis plankton.

Jenis plankton yang banyak ditemukan pada semua stasiun adalah Fragillaria sp, Synedra ulna, Oscillatoria formosa dan Copepod nauplius. Melimpahnya Fragillaria sp dan Synedra ulna pada semua stasiun diduga karena Fragillaria sp dan Synedra ulna respon terhadap perubahan kondisi lingkungan dibandingkan dengan jenis yang lain. Faktor lingkungan sesuai baik suhu, salinitas, DO dll.

Basmi (2000) menyebutkan bahwa Oscillatoria merupakan jenis plankton yang masuk dalam kelompok $\alpha$-mesosaprobik yang beradaptasi baik di perairan dalam kondisi tercemar ataupun tidak tercemar. Oscillatoria formosa ini awalnya memang menguntungkan karena salah satu sumber bahan protein bagi ikan. Akan tetapi, keberadaannya juga merugikan jika overpopulasi pada suatu perairan. Oscillatoria formosa ini mampu menghasilkan senyawa kimia yaitu Methyl-isoborneol (MIB) dan Geosmin yang bisa menyebabkan bau tanah/lumpur pada daging ikan dan udang yang disebabkan oleh tingginya bahan organik yang mengandung fosfat. Pengukuran data $\mathrm{P}$ perairan menunujukkan nilai yang tinggi. Tingginya $\mathrm{P}$ akan menyebabkan jumlah Oscillatoria formosa melimpah (Jeremy, 2007) (Data penelitian selengkapnya tersaji dalam Tabel 1).

Copepod nauplius merupakan perwakilan zooplankton stadia larva dari Crustaceae yang cukup melimpah di semua stasiun. Copepod nauplius merupakan konsumen fitoplankton pertama yang ada di perairan.

Jumlah jenis plankton yang diperoleh tertinggi pada tambak Kedung Mutih (31 jenis) menyusul tambak Babalan (15 jenis), kemudian tambak Menco (13 jenis), perairan umum Babalan 
(12 jenis) dan perairan umum Menco (10 jenis). Berdasarkan Tabel 1 tambak Kedung Mutih mempunyai jumlah jenis yang tinggi. Hal ini bisa disebabkan karena perairan pada tambak Kedung Mutih lebih sesuai faktor fisika-kimia perairannya. Faktor fisika dan kimia yang mendukung berdasarkan baku mutu kualitas air kelas II (air budidaya) yaitu $\mathrm{DO}$, suhu, $\mathrm{pH}$, salinitas, dan kandungan $\mathrm{N}$ dengan berturut-turut nilainya yaitu $8 \mathrm{mg} / \mathrm{l}, 30^{\circ} \mathrm{C}, 6.5,35 \mathrm{ppt}$ dan 9.43. Faktor fisika kimia yang lebih nyata membedakan tambak Kedung Mutih dengan stasiun lainnya yaitu $\mathrm{pH}$ $(6,5)$ dan kandungan $\mathrm{N}(9,43 \mathrm{mg} / \mathrm{l})$. Kandungan $\mathrm{N}$ pada tambak Kedung Mutih diduga berasal dari perairan itu sendiri (artinya bahwa komposisi tanah dasar yang mengandung $\mathrm{N}$ ) maupun berasal dari akumulasi sisa pakan kegiatan budidaya ikan pada perairan tersebut. Nilai $\mathrm{pH}$ pada tambak Kedung Mutih ini cukup baik untuk kehidupan kultivan maupun plankton yaitu 6,5. Nilai $\mathrm{pH}$ yang cocok sebagaimana baku mutu kualitas air kelas II yaitu antara 6-9. Oleh karena itu, dengan nilai $\mathrm{pH}$ 6,5 proses metabolisme dan laju pertumbuhan akan meningkat. Nilai $\mathrm{pH}$ yang masih memenuhi syarat ini dikarenakan pada tambak Kedung Mutih menurut pemiliknya dilakukan pemberian kapur

Tabel 1. Kelimpahan dan Keanekaragaman Plankton di Perairan Payau Kecamatan Wedung.

\begin{tabular}{|c|c|c|c|c|c|c|}
\hline NO & NAMA SPESIES & $\begin{array}{l}\text { TAMBAK } \\
\text { MENCO }\end{array}$ & $\begin{array}{c}\text { PERAIRAN } \\
\text { UMUM MENCO }\end{array}$ & $\begin{array}{c}\text { TAMBAK } \\
\text { BABALAN }\end{array}$ & $\begin{array}{c}\text { PERAIRAN } \\
\text { UMUM } \\
\text { BABALAN }\end{array}$ & $\begin{array}{c}\text { TAMBAK } \\
\text { KEDUNG } \\
\text { MUTIH }\end{array}$ \\
\hline $\mathbf{A}$ & $\begin{array}{l}\text { FITOPLANKTON } \\
\text { Cyanophyceae }\end{array}$ & & & & & \\
\hline 1 & Anabaena sp & 0 & 0 & 102 & 17 & 0 \\
\hline 2 & Apanothece stagnina & 0 & 0 & 0 & 0 & 51 \\
\hline 3 & Aphanocapsa gravillei & 0 & 0 & 17 & 0 & 0 \\
\hline 4 & Coelosphaerium kuetzingianum & 0 & 0 & 0 & 0 & 17 \\
\hline 5 & Lyngbya confervoides & 0 & 0 & 0 & 0 & 136 \\
\hline 6 & Oscillatoria formosa & 34 & 391 & 1547 & 323 & 136 \\
\hline 7 & Oscillatoria $\mathrm{spp}$ & 0 & 0 & 0 & 0 & 17 \\
\hline B & Dinophyceae & & & & & \\
\hline 8 & Ceratium hirundinella & 17 & 0 & 85 & 0 & 17 \\
\hline 9 & Dinophysis mitra & 0 & 0 & 0 & 0 & 17 \\
\hline 10 & Dinophysis norvegica & 0 & 0 & 85 & 85 & 0 \\
\hline 11 & Dinophysis sp & 0 & 0 & 0 & 17 & 0 \\
\hline 13 & Prorocentrum micans & 102 & 85 & 0 & 0 & 0 \\
\hline 14 & Prorocentrum $\mathrm{sp}$ & 0 & 17 & 34 & 0 & 0 \\
\hline 15 & Protoperidinium tuba & 17 & 0 & 0 & 0 & 85 \\
\hline $\mathbf{C}$ & Charophyceae & & & & & \\
\hline 16 & Gleotrichia $\mathrm{sp}$ & 0 & 0 & 0 & 0 & 17 \\
\hline 17 & Mougeotia sp & 0 & 0 & 0 & 0 & 17 \\
\hline $\mathbf{C}$ & Chlorophyceae & & & & & \\
\hline 18 & Chlorella $\mathrm{sp}$ & 0 & 0 & 0 & 0 & 306 \\
\hline 19 & Closterium moniliferum & 0 & 17 & 0 & 0 & 0 \\
\hline 20 & Mesotaenium caldariorum & 17 & 0 & 0 & 0 & 0 \\
\hline 21 & Tetraedron trigonum & 0 & 0 & 0 & 0 & 17 \\
\hline 22 & Tetraedron tumidulum & 17 & 0 & 0 & 0 & 85 \\
\hline D & Bacillariophyceae & & & & & \\
\hline 23 & Bacillaria paradoxa & 0 & 0 & 17 & 17 & 0 \\
\hline 24 & Chaetoceros $\mathrm{sp}$ & 0 & 0 & 0 & 0 & 17 \\
\hline 25 & Cosinodiscus morphotype & 17 & 0 & 0 & 34 & 0 \\
\hline 28 & Fragilaria $\mathrm{sp}$ & 153 & 221 & 136 & 68 & 68 \\
\hline 29 & Gomphonema sp & 0 & 17 & 0 & 0 & 17 \\
\hline 30 & Guinardia delicatula & 17 & 0 & 17 & 17 & 17 \\
\hline 31 & Gyrosigma baticum & 0 & 68 & 0 & 0 & 17 \\
\hline 32 & Melosira $\mathrm{sp}$ & 0 & 0 & 0 & 0 & 17 \\
\hline 33 & Navicula $\mathrm{sp}$ & 17 & 17 & 51 & 0 & 0 \\
\hline 34 & Pleurosigma morphotype & 0 & 0 & 0 & 0 & 34 \\
\hline 35 & Pseudo-nitzshia seriata & 0 & 0 & 0 & 0 & 34 \\
\hline
\end{tabular}




\begin{tabular}{|c|c|c|c|c|c|c|}
\hline 36 & Rhizosolenia stiliformis & 0 & 0 & 0 & 0 & 136 \\
\hline 37 & Synedra ulna & 34 & 85 & 119 & 68 & 255 \\
\hline & $\begin{array}{l}\text { ZOOPLANKTON } \\
\text { Branchiopoda }\end{array}$ & & & & & \\
\hline 38 & Daphnia longispina & 0 & 0 & 17 & 0 & 0 \\
\hline 39 & $\begin{array}{l}\text { Diaphanosoma sp } \\
\text { Maxillopoda }\end{array}$ & 0 & 0 & 0 & 0 & 17 \\
\hline 40 & Acanthocyclops robustus & 34 & 0 & 425 & 102 & 0 \\
\hline 41 & Copepod nauplius & 102 & 170 & 1071 & 187 & 119 \\
\hline 42 & $\begin{array}{l}\text { Cyclops scutifer } \\
\text { Ciliophora }\end{array}$ & 0 & 0 & 17 & 17 & 0 \\
\hline 43 & $\begin{array}{l}\text { Rhabdonella lohmanni } \\
\text { Flagellata }\end{array}$ & 0 & 0 & 0 & 0 & 17 \\
\hline 44 & $\begin{array}{l}\text { Chromolina ovalis } \\
\text { Oligotrichea }\end{array}$ & 0 & 0 & 0 & 0 & 17 \\
\hline 45 & Tintinnopsis sp & 0 & 0 & 0 & 0 & 17 \\
\hline & Jumlah jenis & 13 & 10 & 15 & 12 & 31 \\
\hline & Jumlah total individu (N) & 578 & 1088 & 3740 & 952 & 1819 \\
\hline & Indeks keanekaragaman (H') & 2.19 & 1.81 & 1.69 & 2.1 & 2.91 \\
\hline & Indeks perataan $(\mathrm{E})$ & 0.85 & 0.79 & 0.63 & 0.8 & 0.84 \\
\hline
\end{tabular}

Berdasarkan Tabel 1 juga didapatkan jumlah jenis terendah yaitu pada perairan umum Menco yang hanya 10 jenis. Perairan umum Menco sangat berbeda dengan tambak Kedung Mutih baik dari kondisi plankton, treatmen maupun kondisi fisika kimia perairannya.

Jumlah jenis pada stasiun lainnya seperti pada tambak Menco, tambak Babalan dan perairan umum Babalan dipengaruhi oleh faktor fisika kimia seperti salinitas, $\mathrm{pH}$, kandungan $\mathrm{N}$ dan $\mathrm{P}$ serta faktor biologi (pemangsaan ikan). Tambak Menco dan tambak Babalan memiliki salinitas yang terlalu tinggi yaitu sebesar $46 \mathrm{ppt}$ dan $49 \mathrm{ppt}$. Tambak Menco dan Babalan ini berbeda dengan tambak lainnya karena selama musim kemarau dilaksanakan kegiatan pembuatan garam. Sekalipun sudah memasuki musim hujan, tetapi kandungan garam air tambak cenderung tidak banyak berubah karena terisolasi (dan kurang atau lambat pengencerannya), sehingga menyebabkan kadar garam tinggi. Salinitas pada perairan umum Babalan yaitu 35 ppt masih bisa untuk kehidupan kultivan bandeng, namun bagi udang pertumbuhannya lebih lambat (Poernomo, 1989).

Disamping salinitas dan nutrient, nilai $\mathrm{pH}$ pada tambak Menco, tambak Babalan dan perairan umum Babalan rendah yaitu berturut-turut 4,37, 4,55 dan 4,55. Nilai $\mathrm{pH}$ yang rendah ini bisa dimungkinkan karena tingginya bahan organik yang mengalami proses dekomposisi pada perairan, sehingga menghasilkan asam-asam organik. Hasil asam-asam organik yang tinggi akan menurunkan nilai $\mathrm{pH}$. Hal tersebut bisa dilihat dari nilai $\mathrm{N}$ dan $\mathrm{P}$ pada perairan tersebut yang relatif tinggi yaitu $\mathrm{N}$ antara $18,21 \mathrm{mg} / \mathrm{l}-$ 20,436 mg/l dan P antara 0,42 mg/l - 0,69 mg/l, sehingga memungkinkan proses dekomposisi juga akan menghasilkan asam organik yang tinggi. Nilai $\mathrm{pH}$ yang cocok sebagaimana baku mutu kualitas air kelas II antara 6-9. Oleh karena itu, dengan nilai $\mathrm{pH}$ dibawah 6 proses metabolisme dan laju pertumbuhan akan terganggu.

Faktor pendukung yang lain yaitu nilai $\mathrm{N}$ dan P pada tambak Menco sebesar 18,21 mg/l dan $\mathrm{P}$ sebesar $0,675 \mathrm{mg} / \mathrm{l}$. Sementara pada tambak Babalan nilai $\mathrm{N}$ sebesar 20,436 mg/l \& P $\quad 0,69$ $\mathrm{mg} / \mathrm{l}$. Perairan umum Babalan nilai N $(8,326 \mathrm{mg} / \mathrm{l})$ masih memenuhi, namun nilai $\mathrm{P}$ sebesar $0,42 \mathrm{mg} / \mathrm{l}$ sudah melampaui batas maksimal. Kemungkinan suplai $\mathrm{P}$ perairan umum berasal dari limbah pertanian, limbah rumah tangga yang dekat dengan stasiun tersebut. Sementara baku mutu kualitas air kelas II, batas maksimal nilai $\mathrm{N}$ adalah $10 \mathrm{mg} / \mathrm{l}$ dan batas maksimal nilai $\mathrm{P}$ adalah $0,2 \mathrm{mg} / \mathrm{l}$. Tingginya nilai $\mathrm{N}$ dan $\mathrm{P}$ pada tambak Menco dan tambak Babalan bisa disebabkan praktek budidaya yang kurang benar, seperti pemberian pakan yang berlebihan di perairan tersebut. Jumlah total individu $(\mathrm{N})$ tertinggi pada tambak Babalan (3740 ind/l), menyusul tambak Kedung Mutih (1819 ind/l), kemudian perairan umum Menco (1088 ind/l), perairan umum Babalan (952 ind/l), dan yang terendah pada tambak Menco (578 ind/l) (Tabel 1). Hasil menunjukkan bahwa pada jumlah 
jenis tertinggi tidak diikuti dengan jumlah total individu tertinggi juga. Hal tersebut menunjukkan bahwa adanya faktor fisika kimia yang berbeda seperti : salinitas, $\mathrm{pH}$ dan nutrient yang menjadi faktor pembatas kelimpahan plankton pada perairan tersebut. Data fisika kimia selengkapnya tersaji dalam Tabel 2.

Berdasarkan hasil penelitian indeks keanekaragaman Shannon Wiener ( $\left.\mathrm{H}^{\prime}\right)$ dan indeks pemerataan (e) perairan di Kecamatan Wedung bervariasi berturut-turut antara 1,69-2,91 dan 0,630,85 . Dengan nilai tertinggi di tambak Kedung Mutih dan terkecil di tambak Babalan. Kisaran indeks tersebut cenderung sedang-tinggi yang mengindikasikan lingkungan stabil dan sangat stabil dengan aliran energi yang kompleks. Hal ini dikaitkan dengan banyaknya aktifitas, baik tekanan kondisi lingkungan, penyebaran individu tiap spesies dan budidaya yang kurang selaras.

Faktor fisika kimia secara umum kurang layak dalam kisaran hidup biota yang ada di perairan tersebut. Kondisi musim hujan ini kualitas air tambak maupun perairan umum, meliputi parameter fisika dan kimia cenderung tidak stabil dan sering terjadi penurunan kualitas perairan secara drastis (Marindro, 2008)

Pengukuran suhu pada setiap stasiun didapatkan kisaran suhu antara $26-30^{\circ} \mathrm{C}$. Nilai tersebut memenuhi standar baku mutu. Hal ini berarti kualitas perairan di Kawasan Kecamatan Wedung masih layak untuk budidaya. Hasil pengukuran DO di perairan umum dan perairan tambak Kecamatan Wedung selama penelitian berkisar antara 5,3-8 mg/l cukup optimal bagi pertumbuhan kultivan. Oksigen yang cukup sangat berguna untuk pernafasan kultivan itu sendiri dan untuk mencegah terbentuknya hidrogen sulfida dalam air dan keasaman air.

Berdasarkan hasil penelitian yang dilakukan, salinititas berkisar antara 15-49 ppt, pada beberapa stasiun yaitu tambak Menco dan tambak Babalan kadar salinitas ini sangat tinggi untuk kehidupan ikan maupun udang. Hal tersebut bisa mengakibatkan kultivan mati (seperti udang) dan biota asosiasi tidak cocok hidup pada salinitas yang tinggi (di atas $35 \mathrm{ppt}$ ). Semakin tinggi salinitas maka akan semakin cepat pula konsumsi oksigen. Sedangkan untuk stasiun yang lain yakni perairan umum Menco dan perairan umum Babalan serta tambak Kedung Mutih masih sesuai untuk kehidupan plankton dan kultivan. Salinitas 35-40 ppt masih bisa dilakukan, akan tetapi pertumbuhan plankton dan kultivan ini lebih lambat dibandingkan dengan salinitas 15-25 ppt (Poernomo, 1989).

Berdasarkan hasil pengukuran $\mathrm{pH}$ yang didapatkan selama penelitian $\mathrm{pH}$ berkisar antara 4,11-6,5. Kecuali tambak Kedung Mutih yang mempunyai nilai $\mathrm{pH}$ 6,5. Acuan : standar baku mutu $\mathrm{pH}$ antara 6-9. Hal ini menunjukkan pada semua stasiun $\mathrm{pH}$ bersifat asam sehingga kurang mendukung untuk kehidupan plankton dan kultivan. Nilai turbiditas yang didapat pada semua stasiun yaitu berkisar antar 105-198 NTU. Ini merupakan nilai turbiditas yang terlalu tinggi. Kisaran nilai kekeruhan berkisar antara 2-30 NTU (Wisman, 2013).

Tabel 2 Data Fisika Kimia Per Stasiun

\begin{tabular}{ccccccc}
\hline Parameter & $\begin{array}{c}\text { Tambak } \\
\text { Menco }\end{array}$ & $\begin{array}{c}\text { Perairan } \\
\text { Umum } \\
\text { Menco }\end{array}$ & $\begin{array}{c}\text { Tambak } \\
\text { Babalan }\end{array}$ & $\begin{array}{c}\text { Perairan } \\
\text { Umum } \\
\text { Babalan }\end{array}$ & $\begin{array}{c}\text { Tambak } \\
\text { Kedung } \\
\text { Mutih }\end{array}$ & Standar \\
\hline DO (mg/l) & 7.64 & 5.3 & 7.9 & 7.45 & 8 & 4 \\
Suhu $\left({ }^{\mathbf{0}} \mathbf{C}\right)$ & 26.1 & 26 & 26 & 26.5 & 30 & Deviasi 3 \\
Salinitas (ppt) & 46 & 15 & 49 & 35 & 35 & $15-30$ \\
pH & 4.37 & 4.11 & 4.55 & 4.55 & 6.5 & $6-9$ \\
Turbiditas (NTU) & 146 & 198 & 105 & 157.5 & 105.75 & $2-30$ \\
N (mg/l) & 18.21 & 12.72 & 20.436 & 8.326 & 9.43 & 10
\end{tabular}




\begin{tabular}{ccccccc}
$\mathbf{P}(\mathbf{m g} / \mathbf{l})$ & 0.675 & 0.385 & 0.69 & 0.42 & 0.449 & 0,2 \\
Bahan Organik (\%) & 17.85 & 15.68 & 28.44 & 20.24 & 12.76 & $<9,0$ \\
\hline
\end{tabular}

Berdasarkan hasil penelitian nilai $\mathrm{N}$ pada semua stasiun yaitu berkisar 8,326-20,436 mg/l. Hal ini berarti kandungan $\mathrm{N}$ dalam perairan terlalu tinggi sehingga membahayakan perairan, karena memicu blooming plankton. Adapun nilai fosfat yang didapat berkisar antara 0,385-0,69 $\mathrm{mg} / \mathrm{l}$. Hal ini berarti nilai terlalu tinggi fosfat dalam perairan sehingga menyebabkan eutrofikasi yang akan mengakibatkan melimpahnya fitoplankton. Kandungan oksigen terlarutnya bisa menurun secara tiba-tiba dan $\mathrm{pH}$ juga turun (Wardoyo, 1982). Kandungan bahan organik pada semua stasiun berkisar antara $12.76 \%-28.44 \%$. Nilai tersebut melampaui batas maksimal baku mutu budidaya.

Berdasarkan Tabel 2 ditemukan perbedaan antara perairan tambak dengan perairan umum diantaranya salinitas, kandungan $\mathrm{N}$ dan $\mathrm{P}$. Salinitas yang lebih tinggi ditemukan pada tambak mengindikasikan ada kandungan garam yang dimungkinkan masih terisolasi pada perairan tambak karena adanya siklus penggaraman pada saat musim kemarau. Salinitas yang tinggi tersebut yang dimungkinkan menjadi faktor pembatas kehidupan biota yang ada di perairan tambak. Khususnya tambak Menco dan tambak Babalan. Kandungan $\mathrm{N}$ dan $\mathrm{P}$ yang lebih tinggi dibandingkan perairan umum membuktikan bahwa pada tambak ada akumulasi $\mathrm{N}$ dan $\mathrm{P}$, misalnya dari pakan maupun dari sisa metabolisme kultivan yang dibudidayakan

\section{KESIMPULAN}

Plankton yang diperoleh selama penelitian di perairan payau Kecamatan Wedung adalah 45 jenis terdiri atas fitoplankton 37 jenis dan zooplankton 8 jenis. Jenis plankton yang banyak ditemukan pada semua stasiun adalah Fragillaria sp, Synedra ulna, Oscillatoria formosa dan Copepod nauplius. Tingkat keanekaragaman jenis yang ada pada perairan Kecamatan Wedung sedang sampai tinggi (1,69-2,91), dengan kategori kestabilan komunitas plankton sedang sampai tinggi dengan tingkat pemerataan jenis sedang sampai tinggi. Kualitas air tambak berdasarkan suhu, pH, DO, salinitas, Turbiditas, Nitrat, fosfat dan bahan organik, hanya suhu dan DO yang masih memenuhi baku mutu untuk tambak budidaya.

\section{SARAN PENELITIAN}

- Perlu ditambahkan pakan alami bagi tambak yang mempunyai kelimpahan plankton yang rendah.

- Perlu dilakukan pemupukan terkendali untuk menjaga kesuburan kualitas air, sehingga pakan alami tumbuh tetapi tidak memicu blooming algae. Penambahan kapur pada perairan tersebut untuk meningkatkan nilai $\mathrm{pH}$ yang diketahui cukup rendah dan kurang begitu layak untuk budidaya.

Perlu dilakukan budidaya polikultur dengan rumput laut untuk memperbaiki kualitas perairan Kecamatan Wedung.

\section{DAFTAR PUSTAKA}

APHA (American Public Health Association). 2005. Standard Methods for Examination of Water and Wastewater. Twentieth edition. APHA-AWWA-WEF, Washington, D.C., p. 10-2-10-18.

Basmi, J. 2000. Planktonologi Sebagai Indikator Pencemaran Perairan. Fakultas Perikanan dan Ilmu Kelautan. Institut Pertanian Bogor, Bogor.

Champalbert, G., M. Pagano, P. Sene, and D. Corbin. 2007. Relationship between mesoand macro-zooplankton communities and hydrology in the Senegal River Estuary. Estuarine, Costal and Shelf Science 74: 381-394.

Jeremy D, Picket. 2007. Green Algae: Structure, Reproduction \& Evolution in the Genera. Sinauer Ass.Inc. Massachusettes.

Marindro. 2008. Budidaya Perikanan Tambak. http://www.ourblogtemplates.com. Diakses 20 Agustus 2015.

Muharram, N. 2006. Struktur Komunitas Perifiton dan Fitoplankton di Bagian Hulu 
Sungai Ciliwung, Jawa Barat. Skripsi. Departemen Sumberdaya Perairan. Fakultas Perikanan dan Ilmu Kelautan. Institut Pertanian Bogor

Odum, E.P. 1998. Dasar - dasar Ekologi. Gajah Mada Universitas Press. Yogyakarta.

Poernomo dalam Birner, A. 1989. Budidaya Air. Yayasan Obor Indonesia. Jakarta.
Wardoyo, S. T. H. 1982. Water Analysis Manual Tropical Aquatic Biology Program. Biotrop_Seamed. Bogor

Widowati, Lestari Lakhsmi. 2004. Analisis Kesesuaian Perairan Tambak di Kabupaten Demak Ditinjau dari Aspek Produktivitas Primer Menggunakan Penginderaan Jauh. Thesis. Program Studi Magister Manajemen Sumberdaya Pantai. Universitas Diponegoro. Semarang 